\title{
Productive losses on broiler preslaughter operations: effects of the distance from farms to abattoirs and of lairage time in a climatized holding area ${ }^{1}$
}

\author{
Frederico Márcio Corrêa Vieira ${ }^{2}$, Iran José Oliveira da Silva², José Antonio Delfino Barbosa \\ Filho $^{3}$, Afrânio Márcio Corrêa Vieira ${ }^{4}$
}

\author{
1 Pesquisa financiada pela FAPESP. \\ 2 Núcleo de Pesquisa em Ambiência - NUPEA/ESALQ/USP, Piracicaba, SP, Brazil. \\ ${ }^{3}$ Departamento de Engenharia Agrícola - UFC, Fortaleza, CE, Brazil. \\ ${ }^{4}$ Departamento de Estatística - UnB, Brasília, DF, Brazil.
}

\begin{abstract}
This work aimed to assess the effects of preslaughter lairage time on the welfare and mortality of broilers transported in different farm-abattoir distances. It was evaluated 215 poultry transport trucks from a commercial poultry slaughterhouse from 2006 to 2007. Data were obtained from the holding area acclimatized through fans and water misting in the mornings, afternoons and at night. The thermal variables (temperature and relative humidity), distance, lairage time and density of birds per cage were considered in the analysis. The effects of distance and lairage time were important in the variation of rectal temperature of the animals and on the number of dead animals per truck. Two models were developed (mean and dispersion), for each response variable in function of the interaction between lairage time and distance. As the lairage time in the holding area increased, the rectal temperature of the birds was reduced for all the studied distances. In farm-abattoir distances higher than $25 \mathrm{~km}$, mortality was low when lairage time was lower than 1 hour. However, for distances below $25 \mathrm{~km}$, in the same time interval, the number of dead birds was two-fold higher than in the first situation. The adjustment of lairage time has to be done accordingly to the distance provided that the lairage environment is correctly climatized.
\end{abstract}

Key Words: ambience, poultry production, preslaughter handling, slaughterhouse

\section{Perdas produtivas nas operações pré-abate de frangos de corte: efeito da distância entre as granjas e os abatedouros e do tempo de espera em galpão climatizado}

\begin{abstract}
RESUMO - Avaliou-se o efeito do tempo de espera pré-abate no bem-estar e na mortalidade de frangos de corte transportados em diferentes distâncias granjas-abatedouro. Foram avaliados 215 caminhões de transporte de um abatedouro comercial, entre os anos de 2006 e 2007. Os dados foram obtidos no galpão de espera, climatizado por meio de ventiladores e nebulizadores, nos períodos manhã, tarde e noite. As variáveis térmicas (temperatura e umidade relativa), distância, tempo de espera e densidade de aves por caixa foram consideradas na análise. Destacaram-se os efeitos da distância e do tempo de espera na variação da temperatura retal dos animais e do número de aves mortas por caminhão. Foram desenvolvidos dois modelos (média e dispersão) para cada variável-resposta, em função da interação entre tempo de espera e distância. Com o aumento do tempo de espera nos galpões, reduziu-se a temperatura retal das aves, para todas as distâncias estudadas. Em distâncias granjas-abatedouro superiores a $25 \mathrm{~km}$, a mortalidade foi baixa quando o tempo de espera adotado foi inferior a 1 hora. No mesmo intervalo de tempo para distâncias abaixo de $25 \mathrm{~km}$, no entanto, o número de aves mortas dobrou em relação à primeira situação. O ajuste do tempo de espera deve ser feito de acordo com a distância, desde que o ambiente de espera seja devidamente climatizado.
\end{abstract}

Palavras-chave: abatedouro, ambiência, avicultura, manejo pré-abate

\section{Introduction}

Due to the increasing technological advance in the poultry industry, the assessment of factors that have influence on loss reduction is important, even if it is punctual or generalized throughout the productive process. The most critical loss for the poultry industry is the number of losses caused by deaths during the preslaughter operations, which is the extreme indicator of poor welfare (Petracci et al., 2006). During the hottest periods, the occurrence of deaths before arrival at processing line might be upper than $1 \%$, leading to losses above 300,000 dollars per year (Ritz et al., 2005). 
The time which broilers stay inside the transport trucks is variable during the loading and transport. These conditions vary according to each country, local climate conditions and with the type of transportation used. However, some journeys might last up to 3 hours and the birds are confined inside crates up to 12 hours, depending on the dynamic of whole process (Akşit et al., 2006).

High mortality rates were found in distances higher than $100 \mathrm{~km}$ at Czech Republic and the reduction of journey between farms and slaughterhouse was recommended (Voslarova et al., 2007).

Considering the difficulties to reduce these distances and the high values of temperature and relative humidity in tropical regions, the lairage time in climatized holding areas might be important for thermal comfort and survival of the birds. In environment with low ventilation or without climatization, lairage times lower than 2 hours were recommended by Warriss et al. (1999), who worked with productive losses on preslaughter losses in the United Kingdom. In acclimatized environment, Quinn et al. (1998) suggested time intervals from 2 to 4 hours. The increasing or reducing of lairage time due to specific distances can negatively affect meat quality (Bressan \& Beraquet, 2002). However, at the present, the evidence concerning the relationship between stressful factors, welfare and broilers mortality is little known, mainly on tropical climate regions.

This work aimed to study, through rectal temperature and mortality rates, the effect of preslaughter lairage time and distance between farm and slaughterhouse on broiler welfare.

\section{Material and Methods}

The trial was conducted in a commercial poultry processing plant $\left(22^{\circ} 01^{\prime} 03^{\prime \prime} \mathrm{S}, 47^{\circ} 53^{\prime} 27^{\prime \prime} \mathrm{W}\right.$; $\left.856 \mathrm{~m}\right)$. The location is characterized by a tropical climate ' $\mathrm{Cwa}$ ' according to Köppen's classification, characterized by warm and wet season from October to March, with mean temperature higher than $22^{\circ} \mathrm{C}$, and a dry season from June to August, with an average temperature lower than $18^{\circ} \mathrm{C}$ (Embrapa Pecuária Sudeste, 2007). Data were obtained from the holding area at the slaughterhouse, from October 2006 and March 2007, when 215 broiler transport trucks housed at holding area were assessed.

This lairage is consisted of an open building (approximately $23.70 \mathrm{~m} \times 19.22 \mathrm{~m} \times 5 \mathrm{~m}$ high, with a total area of $455.5 \mathrm{~m}^{2}$ ), with galvanized steel roof and 6 metallic trusses. Environmental climatization was achieved by fans placed on pillars and trusses (4 lines of 7 fans each), whose air flow was $300 \mathrm{~m}^{3} / \mathrm{min}$ and power of $0.5 \mathrm{hp}$, whilst 8 high pressure water misting sets were intercalated with fans, each one with 25 nozzles. The sides were equipped with polypropylene panels during summer for protection against direct solar radiation inside the building.

This building housed 8 poultry transport trucks, each one with 486 boxes, with the average capacity of 7 birds per crate. These crates had the following dimensions: $75 \mathrm{~cm} \times$ $60 \mathrm{~cm} \times 30 \mathrm{~cm}$ high. The animals used on this trial were Cobb breed broilers, from 6 to 7 weeks of age, with average body weight of $2 \mathrm{~kg}$.

Daily periods of transport (morning, afternoon and night), density of birds per crate, distance between farmslaughterhouse, lairage time and the involved thermal factors (temperature and relative humidity) were the factors assessed in this study. For this work, the effects of different lairage time intervals combined with different distances (Figure 1) were evidenced.

The lairage time was considered as a period of permanence in the slaughterhouse, between the truck arrival and slaughter of the animal. The fasting time adopted in each load was 8 hours and all time intervals adopted in the preslaughter operations (catching, loading, transport and lairage at slaughterhouse) was included in this feed withdrawal time.

The rectal temperature and the number of dead chickens were the physiological and the productive variables, respectively. In order to get an estimate of the rectal temperature, five birds were randomly taken from a crate of each studied truck, at the arrival of the truck at holding area and at departure from lairage to the processing plant.

The difference between the rectal temperature taken at the departure and at the arrival was included in the statistical analysis (difference of rectal temperature) with the objective

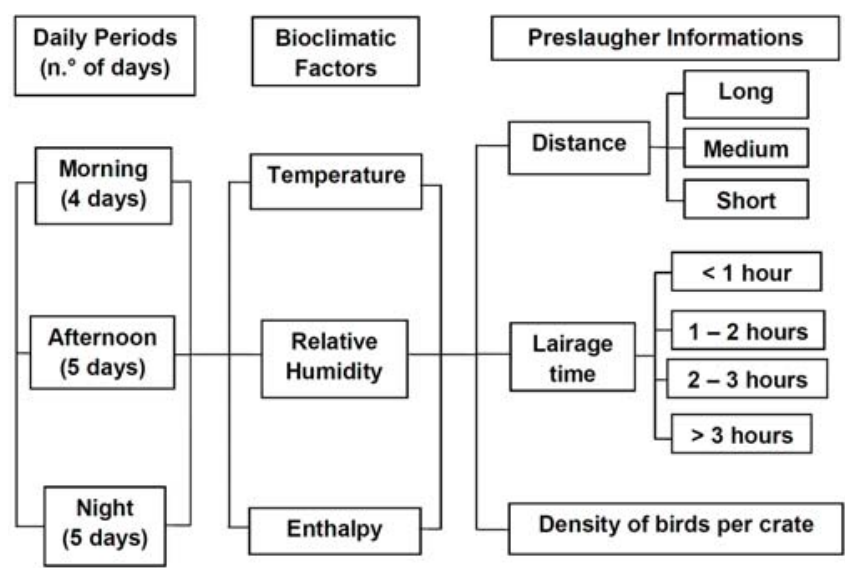

Figure 1 - Flowchart of explanatory variables involved on preslaughter operations. 
to verify a reduction or increasing of rectal temperature of broilers, due to lairage climatization. The number of dead losses per truck was achieved in the database of the industry.

Data were analyzed using a Double Generalized Linear Model (DGLM), an extension of Generalized Linear Models (GLM), which provides a framework for modeling the dispersion in generalized linear models as well as the mean (Vieira, A., 2008). The difference of rectal temperature was considered in this study as a response variable with normal distribution, with the mean linked to a linear predictor through an identity function. The number of dead birds was treated as a response variable with Poisson distribution. The logarithmic function was assumed to make a link between the model linear predictor and the expected value of response variable and for the link function was also assumed as a logarithmic function which guarantee positive values for the expected dispersion parameter $(\hat{\phi})$.

The DGLM for the two response variables was selected based on the Wald tests, with the purpose to test the hypothesis about the true contribution of these factors and interactions on the statistical model (Knight, 2000). This test is an extension of the Student's $t$ test, widely used in general linear regression analysis. Complementary to the Wald test, a residual analysis was performed to verify the model assumptions, based on deviance residuals, fitted values, q-q plots, scale-location plot and Cook's distance, widely used in GLM analysis (McCullagh \& Nelder, 1989). The statistical software environment R (R Development Core Team, 2006) was used together with to the $d g l m$ library (Dunn \& Smyth, 2006), for model parameters estimation and for hypothesis test development.

\section{Results and Discussion}

The use of double generalized linear models allowed modeling simultaneously the variability and the features of rectal temperature and poultry mortality. It was possible to identify that the factors affected variability of these features and thus, it was obtained more precise estimates of these factors which influence the average rectal temperature and the expected number of dead birds. The high variability present in this dataset makes it necessary models which deal with superdispersion, probably due to factors which were not considered in models. The DGLM class showed to be informative and robust in this study.

As evidenced by Vieira (2008), the following interactions were observed in the difference of rectal temperature model $(\mathrm{P}<0.05)$ : lairage time, external and internal temperature, density of birds per crate, periods of the day and distance.
In the mortality model, the observed interactions were: lairage time, density of birds per crate, external and internal temperature, and relative humidity. Some of the following interactions between the following variables were not observed: night vs. distance (difference of rectal temperature model); relative humidity vs. afternoon and lairage time vs. night (mortality model).

For assessment of average rectal temperature, the following model was used: $\hat{y}_{1}=-0.661 *+2.05 \cdot 10^{-2} * \mathrm{e}-1.74 \cdot 10^{-2} * \mathrm{~d}$ $+2.90 \cdot 10^{-5 *} \mathrm{ed}$, and, for the average number of dead birds it was used the following: $\hat{y}_{2}=\exp \left(-49.71^{*}+2.36 \cdot 10^{-2 *}\right.$ $\left.e-2.81 \cdot 10^{-2^{*}} d+1.62 \cdot 10^{-5^{*}} e d\right)$,

where $\hat{y}_{1}=$ estimated mean parameter (rectal temperature); $\hat{y}_{2}=$ estimated mean parameter (mortality); $e$ = lairage time; $d=$ distance between farms and slaughterhouse; ${ }^{N S}$ nonsignificant; * significantly difference $(\mathrm{P}<0,05)$, derived by Wald test.

Great contributions of lairage time were observed jointly with distance on the difference of rectal temperature and mortality estimation. Even with high significant relationship of each explanatory variable with mortality and rectal temperature, the distance by itself does not explain the variations on the response of the animal, given the importance of time which the birds stayed under stress on the truck (Warriss et al., 1992). Furthermore, according to Gregory (1994), the relationship between losses and distance is not linear. The increase of losses is higher with the factor time, due to stress conditions inside the load.

For dispersion assessment, the following models were used for difference of rectal temperature and number of dead birds, respectively: $\hat{\phi}_{1}=\exp \left(0,25^{\mathrm{NS}}+1.89^{*} a+1.31^{*} n\right.$ $\left.+0.15^{*} t_{1}-0.28^{*} t_{2}+0.05^{*} u_{1}-0.04^{*} u_{2}+0.01^{*} e+0.004^{*} d\right)$, and $\hat{\phi}_{2}=\exp \left(-4.82^{*}+0.09^{*} t_{1}-2.91^{\mathrm{NS}} e^{1}-4.39^{*} e^{2}-4.01^{\mathrm{NS}} t_{2}{ }^{1}\right.$ $\left.-8.69^{*} t_{2}^{2}+0.04^{*} u_{2}-0.81^{*} a-0.19^{\mathrm{NS}} n\right)$, where $\hat{\phi}_{1}=$ expected dispersion parameter (rectal temperature); $\hat{\phi}_{2}=$ expected dispersion parameter (number of dead birds); $a$ = afternoon; $n=$ night; $t_{1}=$ external temperature; $t_{2}=$ internal temperature; $u_{1}=$ external relative humidity; $u_{2}=$ internal relative humidity; $e=$ lairage time; $d=$ distance between farms and slaughterhouse; $e^{1}$, $e^{2}=$ second degree polynomial for lairage time; $t_{2}{ }^{1}, t_{2}{ }^{2}=$ second degree polynomial for internal temperature; NS = non-significant; $*$ significantly difference $(\mathrm{P}<0.05)$ derived by Wald test.

In the dispersion models, the lairage time contributed linear and positively with the increasing difference of rectal temperature variability. However, the contribution on the variability of the number of dead birds were quadratic and negative, indicating that higher or lower lairage time intervals 
tends to produce less variability then intermediate time intervals.

This difference between models can be explained through the stress levels experienced by birds. Rectal temperature is the first indicator of poor welfare of broilers, whereas the mortality is the highest indicator related to stress (Broom, 2007). Increasing values of lairage time tend to elevate the variation of rectal temperature. The excess of climatization results in thermal heterogeneity on the lairage environment causing hypothermia in some birds depending on its localization on the truck, for example more contact with the climatization system, and also body weight and age (Hunter et al., 1999; Barbosa Filho et al., 2009). In relation with the number of dead birds, the adoption of lower or higher lairage time resulted in reduced and less variable mortality, according to the distance and related with the results achieved through the mean model. In other words, when analyzed jointly with other important factors, such as distance between farms and slaughterhouse, the extremes of lairage time had major influence on determining the mortality, despite of the intermediate levels.

The reduction of rectal temperature was expressive as lairage time increased for all traveled distances (Figure 2). In general, for increasing intervals of exposing time to thermal stress, it was observed an increase on rectal temperature of approximately $0.9^{\circ} \mathrm{C}$ (Hunter et al., 1998). According to Silva et al. (2007), who assessed the thermal

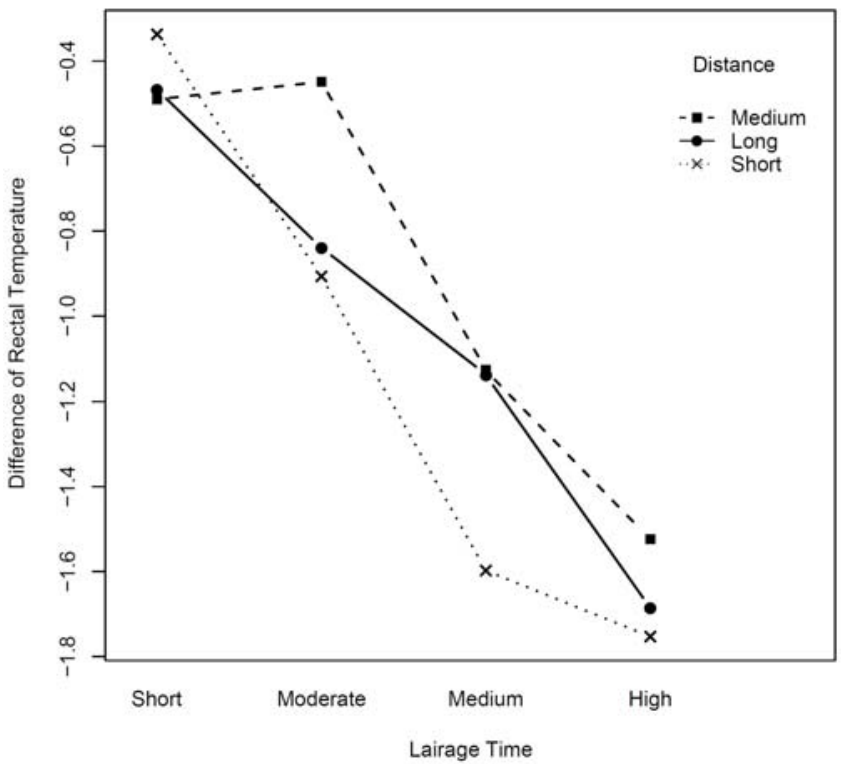

Long = higher than $51 \mathrm{~km}$; Medium = from 25 to $50 \mathrm{~km}$; Short = lower than $24 \mathrm{~km}$; Short = lower than 1 hour; Moderate = from 1 to 2 hours; Medium = from 2 to 3 hours; High $=$ higher than 3 hours.

Figure 2 - Interaction plot of distance between farms and slaughterhouse with the lairage time intervals related to the difference of rectal temperature. stress in simulated transport conditions, in 30 minutes, the birds were under thermal stress, exceeding the lower condition of stress $\left(41.1^{\circ} \mathrm{C}\right)$, which evidenced that, with higher exposing time to higher temperature and relative humidity, the rectal temperature values are lower.

As it was exposed by the same authors, the critical point were achieved in 120 minute time, when birds showed symptoms of thermal collapsing, which resulted in deaths. Thus, the use of climatization systems allows the thermal comfort of broilers, when allied to the factor time. As the lairage interval increases, the reduction on rectal temperature is higher, due to maintenance of temperature and humidity under comfort levels for broilers (Barbosa Filho, 2008).

Under elevated ventilation regimen, the sensible heat loss is high, consequently resulting in a reduction of rectal temperature due to the removal of a great amount of heat from the surface of the broiler(Yahav et al., 2005; Welker etal., 2008).

Considering the distance between farms and slaughterhouse above $25 \mathrm{~km}$, the mortality was lower when it was adopted the short lairage time (Figure 3). However, in the same time interval for short distance, the number of dead birds doubled in relation to the first situation.

The condition of stress during transport might be severe when the distance is increased. The expected mortality in these cases can be $80 \%$ higher in long journeys (Warriss et al., 1992). This raising in the losses related with the increasing of distance was due to the significant

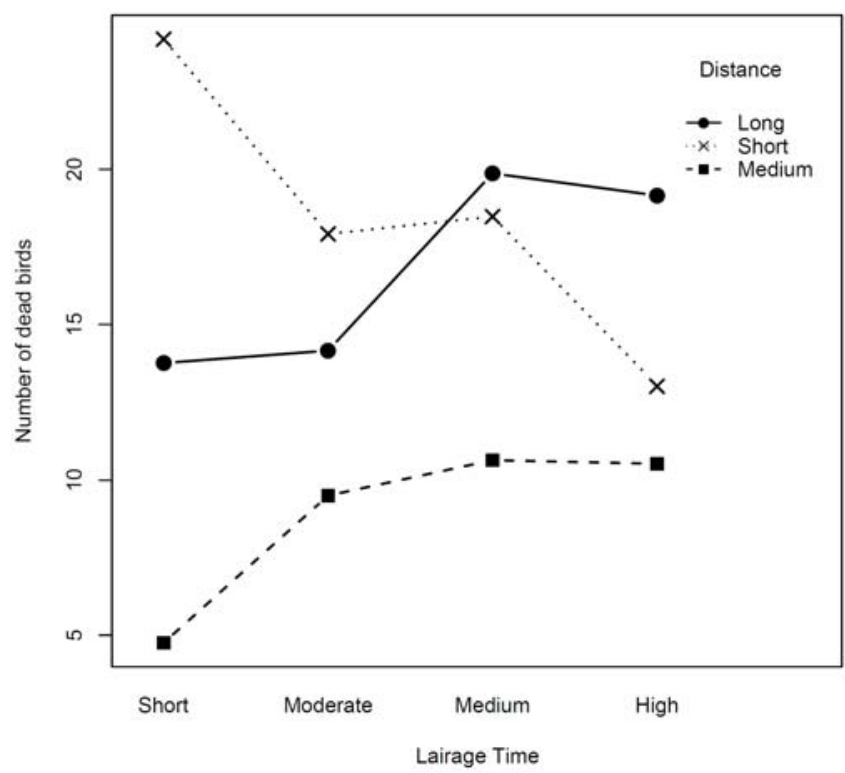

Long = higher than $51 \mathrm{~km}$; Medium = from 25 to $50 \mathrm{~km}$; Short = lower than $24 \mathrm{~km}$ Short = lower than 1 hour; Moderate = from 1 to 2 hours; Medium = from 2 to 3 hours; High = higher than 3 hours.

Figure 3 - Estimated number of dead birds through interaction of distance between farms and slaughterhouse with lairage time. 
reduction of the ability of animals to maintain the necessary biological balance to cope with transport (Cockram, 2007). Long journeys resulted in increasing of the number of dead birds, in order of $0.86 \%$ of mortality, comparatively higher in relation with shorter distances (Vecerek et al., 2006).

The influence of lairage time in a climatized holding area can be explained by the energetic load consumption of birds under stress situation (Mendes, 2001; Savenije et al., 2002; Olanrewaju et al., 2006). The birds showed an accentuated consumption of the energetic load in the first 30 minutes of exposition to a stressor factor, resulting thereafter in an adaptation (Bressan \& Beraquet, 2002). For short distance, the longer lairage time in the climatized area resulted in the return to the initial thermal comfort condition, increasing chances of survival of the flock. In other words, the thermal stress of broilers might be reversible with the climatization during lairage, because they were still sensible to the climatized environment. For longer journeys, the birds exceeded this critical period, reaching the irreversibility due to the depletion of energetic reserves, being shorter the effect of climatization on the returning to the initial thermal comfort of broilers. The long waiting of weak birds during lairage resulted in an increase of the number of dead birds in this time interval. Therefore, the efficiency of climatization is important when it considers the need of reducing thermal stress of broilers, and the distance showed a direct relation to the effects of lairage time, in terms of rectal temperature and mortality.

Aiming to reducing losses, different lairage time is necessary when considering short and long distances, for birds which may recover from transport stress (Table 1).

For longer distances, the time interval from 1 to 2 hours is suitable to reduce the thermal load of the transported flock, without prolonged energetic depletion of broilers, however.

For medium distance, the short time interval is the most appropriated due to the lower stress extension in relation to longer distances. For short distance, the lairage time above 3 hours is the most appropriated for the thermal balance maintenance of broilers.

Table 1 - Recommended values of lairage time in relation to distance and the respective expected mortality rates

\begin{tabular}{|c|c|c|}
\hline Distance (levels) & $\begin{array}{c}\text { Lairage } \\
\text { time (levels) }\end{array}$ & $\begin{array}{c}\% \text { expected } \\
\text { mortality }\end{array}$ \\
\hline Long (higher than $51 \mathrm{~km}$ ) & Moderate (1 -2 hours) & $0.41 *$ \\
\hline Medium (25 - 50 km) & Short (lower than 1 hour) & $0.12 *$ \\
\hline Short (lower than $24 \mathrm{~km}$ ) & High (higher than 3 hours) & $0.41 *$ \\
\hline
\end{tabular}

* $(\mathrm{P}<0.05)$, derived by Wald test.

\section{Conclusions}

In climatized holding areas, the increase of lairage time reduces rectal temperature of broilers, for all travelled distances, improving the welfare condition of animals. However, aiming to reduce pre-slaughter losses of broiler chickens, it is recommended lairage time higher than 2 hours for short distances and lower than 1 hour for travelled distances higher than $50 \mathrm{~km}$.

\section{References}

AKŞIT, M.; YALÇIN, S.; ÖZKAN, S. et al. Effects of temperature during rearing and crating on stress parameters and meat quality or broilers. Poultry Science, v.85, n.11, p.1867-1874, 2006.

BARBOSA FILHO, J.A.D. Caracterização quantiqualitativa das condições bioclimáticas e produtivas nas operações préabate de frangos de corte. 2008. 174f. Tese (Doutorado em Agronomia) - Escola Superior de Agricultura Luiz de Queiroz, Piracicaba.

BARBOSA FILHO, J.A.D.; VIEIRA, F.M.C.; SILVA, I.J.O. et al. Transporte de frangos: caracterização do microclima da carga durante o inverno. Revista Brasileira de Zootecnia, v.38, n.12, p.2442-2446, 2009.

BRESSAN, M.C.; BERAQUET, N.J. Efeito de fatores pré-abate sobre a qualidade da carne de peito de frango. Ciência Agrotécnica, v.26, n.5, p.1049-1059, 2002.

BROOM, D.M. Causes of poor welfare and welfare assessment during handling and transport. In: GRANDIN, T. (Ed.). Livestock handling and transport. 3.ed. Wallingford: $C A B$ International, 2007. 386p.

COCKRAM, M.S. Criteria and potential reasons for maximum journey times for farm animals destined for slaughter. Applied Animal Behaviour Science, v.106, n.4, p.234-243, 2007.

DUNN, P.K.; SMYTH, G.K. [2006]. dglm: Double generalized linear models. $\mathrm{R}$ package version 1.6.1 Disponível em: <http://www.R-project.org> Acesso em: 21/3/2007.

EMBRAPA PECUÁRIA SUDESTE [2007]. Clima e hidrologia. São Carlos: Embrapa Pecuária Sudeste, 2007. Disponível em: <http://www.cppse.embrapa.br/servicos/ dados-meteorologicos> Acesso em: 21/3/2007.

GREGORY, N.G. Preslaughter handling, stunning and slaughter. Meat Science, v.36, p.45-56, 1994.

HUNTER, R.R. Physiological responses of broilers to pre-slaughter lairage: effects of the thermal micro-environment? British Poultry Science, v.39, n.5, Suppl. 1, p.53-54, 1998.

HUNTER R.R.; MITCHELL, M.A.; CARLISLE, A.J. Wetting of broilers during cold weather transport: a major source of physiological stress? British Poultry Science, v.40, n.5, Suppl. 1, p.48-49, 1999.

KNIGHT, K. Mathematical statistics. Boca Raton: Chapman \& Hall, 2000. 502p.

McCULLAGH, P.; NELDER, J.A. Generalized linear models London: Chapman and Hall, 1989. 536p.

MENDES, A.A. Jejum pré-abate em frangos de corte. Revista Brasileira de Ciência Avícola, v.3, n.3, p.199-209, 2001.

OLANREWAJU, H.A.; WONGPICHET, S.; THAXTON, J.P. et al. Stress and acid-base balance in chickens. Poultry Science, v.85, p.1266-1274, 2006.

PETRACCI, M.; BIANCHI, M.; CAVANI, C. et al. Preslaughter mortality in broiler chickens, turkeys and spent hens under commercial slaughtering. Poultry Science, v.85, p.1660-1664, 2006 . 
QUINN, A.D.; KeTTLEWELl, P.J.; MITChell, M.A. et al. Air Movement and the thermal microclimates observed in Poultry Lairages. British Poultry Science, v.39, n.4, p.469-476, 1998.

R DEVELOPMENT CORE TEAM. R: A Language and environment for statistical computing. Vienna: R Foundation for Statistical Computing, 2006. Disponível em: <http://www.R-project.org> Acesso em: 1/3/2007.

RITZ, C.W.; WEBSTER, A.B.; CZARICK, M. Evaluation of hot weather thermal environment and incidence of mortality associated with broiler live haul. Journal of Applied Poultry Research, v.14, n.3, p.594-602, 2005.

SAVENIJE, B.; LAMBOOIJ, E.; GERRITZEN, M.A. et al. Effects of feed deprivation and transport on preslaughter blood metabolites, early postmortem muscle metabolites and meat quality. Poultry Science, v.81, p.699-708.

SILVA, M.A.N.; BARBOSA FILHO, J.A.D.; SILVA, C.J.M. et al. Avaliação do estresse térmico em condição simulada de transporte de frangos de corte. Revista Brasileira de Zootecnia, v.36, n.4, p.1126-1130, 2007 (supl.).

VECEREK, V.; GRBALOVA, S.; VOSLAROVA, E. et al. Effects of travel distance and the season of the year on death rates of broilers transported to poultry processing plants. Poultry Science, v.85, p.1881-1884, 2006.

VIEIRA, A.M.C. Modelagem simultânea de média e dispersão e aplicações na pesquisa agronômica. 2008. 117f. Tese
(Doutorado em Agronomia) - Escola Superior de Agricultura Luiz de Queiroz, Piracicaba.

VIEIRA, F.M.C. Avaliação das perdas e dos fatores bioclimáticos atuantes na condição de espera pré-abate de frangos de corte. 2008. 176f. Dissertação (Mestrado em Agronomia) - Escola Superior de Agricultura Luiz de Queiroz, Piracicaba.

VOSLAROVA, E.; JANACKOVA, B.; VITULA, F. et al. Effects of transport distance and the season of the year on death rates among hens and roosters in transport to poultry processing plants in the Czech Republic in the period from 1997 to 2004. Veterinarni Medicina, v.52, n.6, p.262-266, 2007.

WARRISS, P.D.; BEVIS, E.A.; BROWN, S.N. et al. Longer journeys to processing plants are associated with higher mortality in broiler chickens. British Poultry Science, v.33, p.201-206, 1992.

WARRISS, P.D.; KNOWLES, T.G.; BROWN, S.N. et al. Effects of lairage time on body temperature and glycogen reserves of broiler chickens held in transport modules. Veterinary Record, v.145, p.218-212, 1999.

WELKER, J.S.; ROSA, A.P.; MOURA, D.J. et al. Temperatura corporal de frangos de corte em diferentes sistemas de climatização. Revista Brasileira de Zootecnia, v.37, n.8, p.1463-1467, 2008.

YAHAV, S.; SHINDER, D.; TANNY, J. et al. Sensible heat loss: the broiler's paradox. World's Poultry Science Journal, v.61, p.419-433, 2005 